\title{
Taxonomic Description and Reproductive Behavior of Giant Pangola (Digitaria valida Stent) ${ }^{1}$
}

\author{
A. Sotomayor-Rios, K. F. Schertz, R. Woodbury, and J. Vélez Fortuño $o^{2}$ \\ INTRODUCTION
}

The introduction of forage species is one of the main approaches in attempting to improve forages. An introduction, Giant Pangola, a type of Digitaria valida Stent $^{3}$, Puerto Rico P.I. 2281, appeared to be a promising forage grass in preliminary tests of the Plant Breeding Department of the Agricultural Experiment Station of the University of Puerto Ricos. This grass which was introduced from Cuba is characterized by broad bright glaucous green leaves and upright growth until blooming, at which time it usually starts spreading laterally by stolons.

It has been referred to in the literature as Giant Pangola, Kob grass, and Kob Hill Digitaria $(9,10,11)^{5}$. Giant Pangola, or its Spanish equivalent Pangola Gigante, is the name commonly used because it is of the same genus and resembles Pangola grass (Digilaria decumbens Stent) but grows taller with broader leaves.

Because of the desirable forage characteristics of Giant Pangola it appeared to be useful in a breeding program, but before a selection is used for crossing, its reproductive behavior should be thoroughly understood. Preliminary observations of low seed set raised questions about its potential for breeding. The purpose of the present study was to determine the reproductive behavior of Giant Pangola and to evaluate the possibility of using it in a breeding program. The work included a taxonomic description and species verification, a determination of fertility, and a study of the reproductive processes.

Previous reports include little about such characteristics of this species. The chromosome number of $D$. valida was reported as 24 by Young and Crocker (12), 30 by de Wet (4), and 36 by de Wet and Anderson (5).

1 Contribution from the Agricultural Experiment Station of the University of Puerto Rico, Río Piedras, P.R., and the Federal Experiment Station, U. S. Department of Agriculture, Mayagüez, Puerto Rico.

2 Research Assistant in Plant Breeding, Agricultural Experiment Station, University of Puerto Rico; Plant Geneticist, USDA, ARS, Federal Experiment Station, Mayagüez, P.R.; Associate Taxonomist; and Plant Breeder, Head, Department of Plant Breeding, Agricultural Experiment Station, University of Puerto Rico, Rio Piedras, P.R., respectively.

${ }^{3}$ Verified by Smithsonian Institution, Washington, D. C.

1 Unpublished data.

${ }^{6}$ Italic numbers in parentheses refer to Literature Cited, p. 59. 
Apparently nothing has been published on fertility, microsporogenesis, or megasporogenesis.

This study is of importance because of the possibility of using Giant Pangola in areas now being planted to Pangola grass which it resembles. Pangola grass is the third most important grass in Puerto Rico with an estimated 50,000 cuerdas $^{6}$ in cultivation, but its utilization in a breeding program is limited because of its sterility. This species with 30 chromosomes, reported by Burton (2) and Sheth et al. (7), has meiotic irregularities observed which account for the sterility (7). If Giant Pangola is sufficiently productive and possesses desirable reproductive characteristics, it might be more useful to forage breeders than Pangola grass.

\section{MATERIALS AND METHODS}

Buds for determining meiotic behavior were obtained from field plots at the Rio Piedras Agricultural Experiment Station and at the Gurabo Agricultural Experiment Substation. Percentage seed set was determined from panicles of field-grown plants at these two locations.

Determinations of somatic chromosome number and analyses of meiotic behavior were made in the cytological laboratories of the Federal Experiment Station at Mayagüez. Chromosome counts were made from vigorously growing root tips removed from potted tillers. The root tips were pretreated in 1 part $0.002 \mathrm{M}$ solution of 8-hydroxyquinoline and 1 part aqueous solution of $\alpha$-bromonapthalene for 3 hours at $12^{\circ} \mathrm{C}$. (6). They were then fixed in Farmer's solution and smeared in aceto-orcein by the method of Tjio and Levan 1950 ( 8 ).

A solution of absolute alcohol, chloroform, and glacial acetic acid in a 6:3:1 proportion, was used for fixing microsporocyte material. Smears were made with aceto-carmine, and pollen was stained in IKI solution. Material for megasporogenesis observations was fixed in CRAF, processed through paraffin and stained with haematoxylin.

\section{EXPERIMENTAL RESULTS}

\section{DESCRIPTION}

Inasmuch as Giant Pangola differed in several characters from the original description of $D$. valida (1), it is appropriate to include a short description of this variety.

Giant Pangola is a vigorous tufted plant reaching a height of $1 \mathrm{~m}$. or more and with long, slender, hirsutulose stolons (fig. 1, A and B). The leaves are soft, glaucous, loosely villous, and of a linear shape with a length

- 1 cuerda equals 0.97 acres. 
to $40 \mathrm{~cm}$. and a width to $1 \mathrm{~cm}$. Leaf sheaths are densely villous toward the base end at the node.

The inflorescense is digitate at the base and somewhat scattered above,
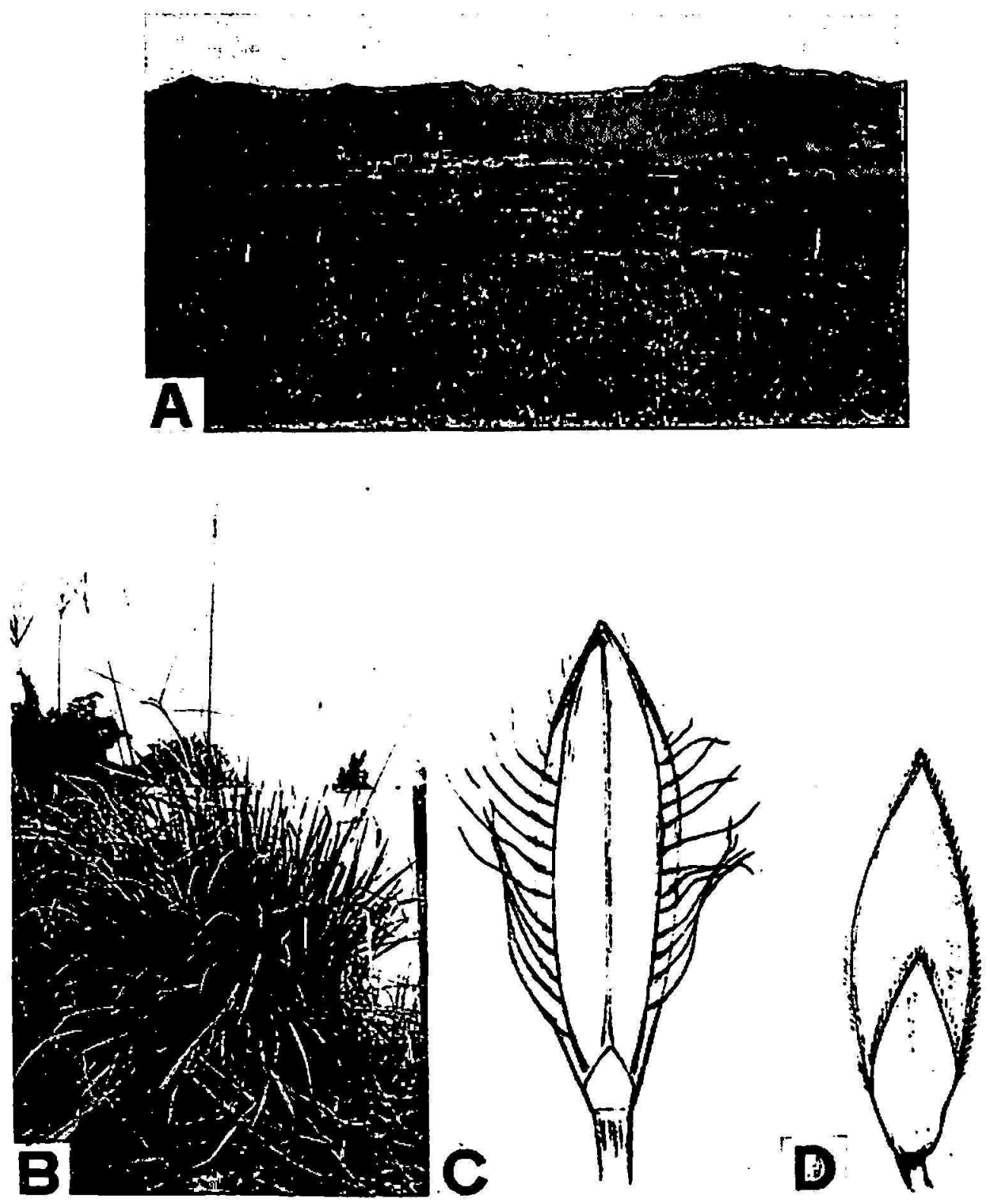

Fig. 1.-A, An experimental plot of (iiant Pangola (Digitaria valida Stent) at the Gurabo Agricultural lexperiment Substation. l'lot size $30^{\prime} \times 30^{\prime}$. B, A close-up of Giant l'angola at the Río P'iedras Agricultural Experiment Station. Height to tip of leaves $20^{\prime \prime}$. C, A spikelet of (Ciant l'angola, dorsal view, $18 \times$, drawn by Julio "Torres. $D$, A spikelet of Ciant Pangola, vent ral view, $16 \times$, drawn by Julio Torres.

producing 6 to 11 racemes 10 to $20 \mathrm{~cm}$. long and $2 \mathrm{~mm}$. wide; the rachis is $1 \mathrm{~mm}$. wide with a $0.3 \mathrm{~mm}$. wing on either side.

Spikelets are lanceolate, 2.6 to $3 \mathrm{~mm}$. long, first glume small but present, second glume two-thirds as long as the spikelet, lemma in-nerved, 3 inner 
prominent, coarsely ciliate along the second pair of nerves; palea membraneous, slightly shorter than the lemmas (fig. 1, C and D).

\section{CHROMOSOME NUMBER AND REPROIUCTIVE BEHAVIOR}

The chromosome number was found to be 42 from observations of roottip smears (fig. 2,A) and was confirmed by chromosome counts in microsporocyte smears.

Meiotic divisions of the microsporocytes were (quite irregular. Multivalent frequency during prophase was high (fig. 2,B), and at first metaphase, univalents, bivalents, trivalents, and quadrivalents were present (fig. 2,C). The mean number of bivalents was 14.5, with a maximum of 18 in one cell. The mean number of univalents, some of which were not on the metaphase

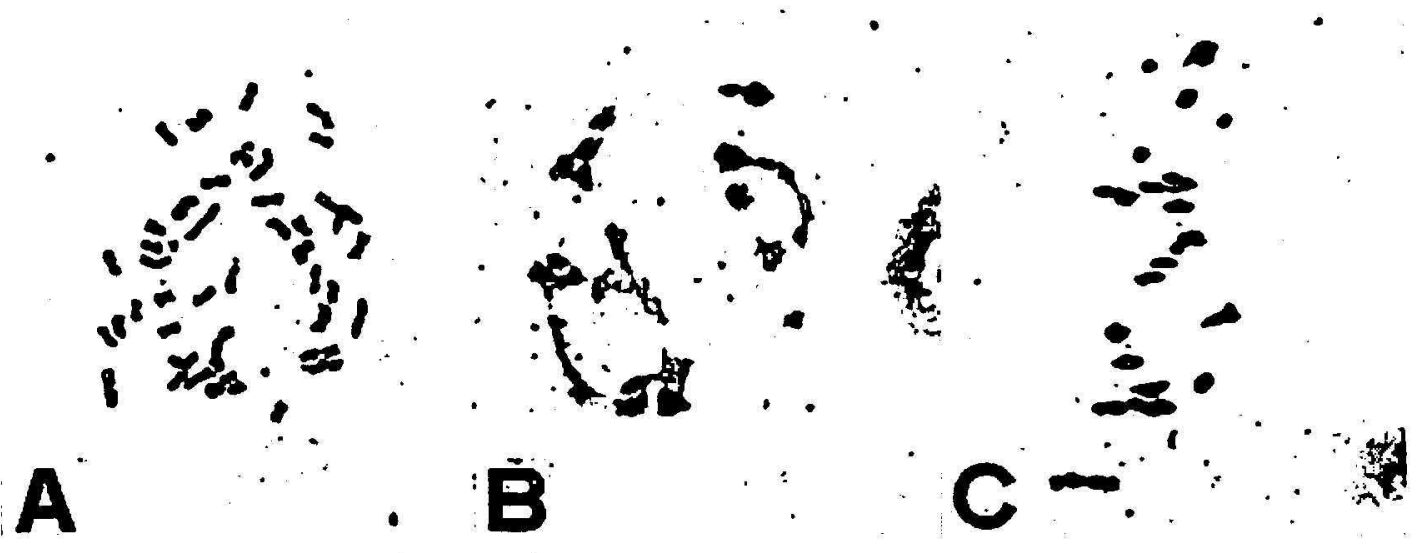

Fig. 2.-A, A smeared root tip) cell of (iiant Pangola with 42 chromosomes; B, prophase I of microsporocyte with multivalents of the same; C, metaphase $I$ with univalents, bivalents, and multivalents of the same. All photomicrographs ca. $800 \times$.

plate. was 4 , with a maximum of 8 . Only rarely was a cell seen with no multivalents at metaphase. The largest number of ehromosomes in multivalent configurations was 17,3 trivalents and 2 cuadrivalents.

Anaphase I was also irregular with all cells observed at this stage possessing univalent chromosomes (fig. $3, \mathrm{~A}$ ). In 100 cells, there was a mean of 3.8 laggards per cell, with one cell having 8 . The laggards usually divided and proceeded toward the poles, but of en they were not included in the nuclei at telophase and in the secondary sporocytes (fig. 3,B). Anaphase I distribution of chromosomes was of ten unequal with as few as 15 observed migrating toward one pole.

lagging chromosomes were frequent at second metaphase and second anaphase, with no normal divisions observed. Microspore quartets contained many micronuclei (fig. 3,C). Of 100 (quartets, all had micronuclei, with a mean number of $4 .(\mathrm{i}$ per spore quartet.

Most of the pollen grains were probably nonfunctional; of 1,000 grains studied only 23 (2.3 per cent) stained completely in IKI solution and these 


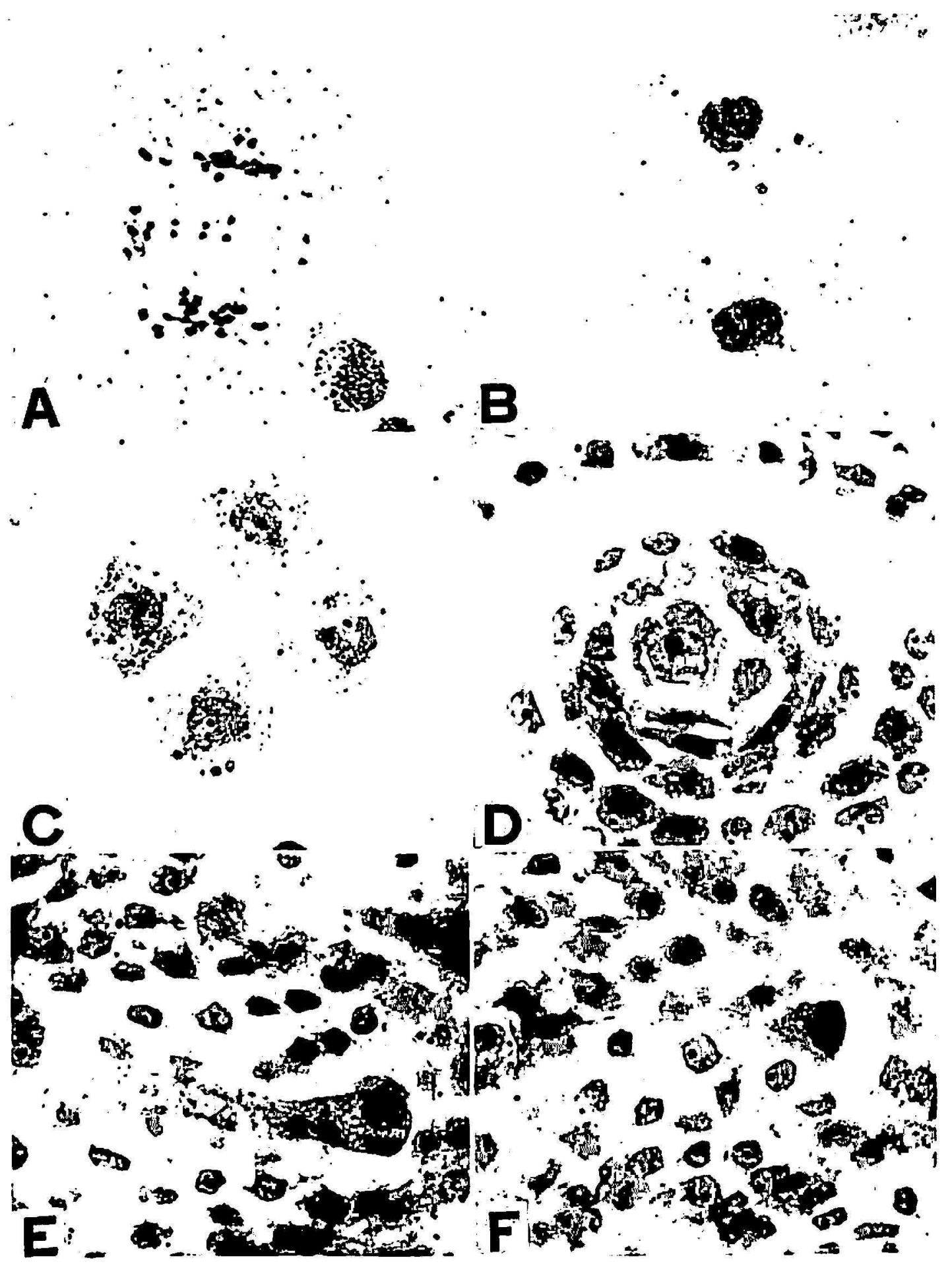

Fig. 3.-A, Late anaphase I with lagging univalents of (iiant Pangola; B, secondary microsporocytes of same with micronuclei; $\mathrm{C}$, microspore quartet of same with micronuclei; D, magasporocyte of same; 1 , megaspore of same enlarged; F, megaspore of same collajsed. All photomicrographs ca. $900 \times$.

were variable in size. Eighty-four pereent of the pollen grains were partly stained, and 14 percent were completely unstained. During megasporogenesis the megasporocyte enlarged (fig. 3,D) and underwent meiotic divisions forming an elongated megaspore (fig. 3,E). In most cases degenera- 
tion was observed to occur after the megaspore was formed. Before meiotic divisions the megaspore collapsed (fig. 3,F); sometimes a cavity was left, but at other times it was filled by nucellar tissue. Normal megagametogenesis was infrequent and probably accounts for the karyopses which developed. Of 2,154 florets examined, 32, or 1.5 percent developed karyopses but none of the seeds germinated.

\section{Discussiox}

The extremely low fertility of Giant Pangola demonstrated in the studies described will limit its use in a breeding program. The constitution of 42 chromosomes is irregular for this species and may account for the abnormalities of microsporogenesis and megagametogenesis which appear to be sufficient to cause the low fertility. Since prerious work $(3,4,12)$ on $D$. valida cytology did not include information on meiosis or fertility, no comparison of reproductive behavior is possible.

Studies of species relationships might aid in explaining the chromosomal irregularities and might provide a clue as to the origin of Giant Pangola. It is possible that the $\mathbf{4 2}$ chromosome selection used in this study is an aneuploid, but its chromosome number would also fill the requirements of an euploid with a basic number of six or of seven. If it has a basic number of six it could be a $7 \mathrm{X}$ type (septaploid) in a series with the previously reported numbers of 24,30 , and 36 for this species. The other alternative, a basic number of seven, is uncommon in this genus, but has been reported for D. sanguinalis (L.) Scop. with $2 \mathrm{~N}^{*}=28$ (3).

Studies of ovule and seed development may help to explain the lack of viability of the seeds obtained.

\section{SLMMARY}

The chromosome number and reproductive behavior of Giant langola, a type of Digilaria valida Stent, were determined to evaluate the possibility of using it in a breeding program. It was also described and verified taxonomically. The observations revealed anomalies which would appear to severely handicap its use in breeding. The somatic chromosome const it ution of 42 is different from those previously reported for this species.

Microsporogenesis was irregular in all cells studied, characterized by multivalent formation, lagging univalents, and micronuclei, and resulted in only 2.3 percent of the pollen grains staining completely in IKI solution.

No degeneration was observed during megasporogenesis but was usually apparent after megaspore formation. It is concluded that the chromosomal irregularities noted may be sufficient to cause the very low seed set and that this low fertility will limit the utilization of Giant Pangola in a breeding program. 


\section{RESUMEN}

Este estudio se realizó con el propósito de determinar el número de cromosomas y el comportamiento reproductivo de la yerba forrajera Pangola Gigante, un tipo de Digitaria valida Stent, con el fin de establecer su utilidad potencial en un programa de mejoramiento genético. Esta especie fué tambien descrita y verificada taxonómicamente.

Se encontraron 42 cromosomas somáticos cuyo número difiere de los anteriormente informados para esta especie: 24,30 y 36 .

El proceso de microsporogénesis resultó irregular en todas las células estudiadas y se caracterizo por agrupaciones multivalentes, univalentes retardados y micronúcleos. El polen tiñó completamente en solución de IKI (Ioduro de potasa iódico) en un 2.3 por ciento solamente.

No se observó degeneración durante el proceso de megasporogénesis, pero sí fué visible después de la formación de la megaspora.

Se concluye que las irregularidades cromosómicas fueron suficientes para la escasa formación de semilla obtenida y que este bajo grado de fertilidad limitará seriamente la utilización de la Pangola Gigante en un programa de mejoramiento genético.

\section{LITERATURE CITED}

1. Bothalia 3 148-9, 1930.

2. Burton, G. W., A Cytological study of some species in the tribe Paniceae, Amer. J. Bot. 29 355-9, 1942.

3. Church, G. L., Meiotic phenomena in certain Gramineae II; Paniceae and Andropogoneae, Bot. Gaz. 88 63-84, 1929.

4. de Wet, J. M. J., Chromosome numbers of a few South African grasses, Cytologia 19 97-103, 1954.

5. de Wet, J. M. J., and Anderson, L. J., Chromosome numbers in Transvaal grasses, Cytologia 21 1-10, 1956.

6. Mitra, J., and Randolph, L. F., Karyotype analysis in bulbous iris, Bot. Gaz. 120 125-35, 1959.

7. Sheth, A. A., Yu, Lillian, and Edwardson, J., Sterility in Pangolagrass (Digitaria decumbens Stent) Agron. J. 48 505-7, 1956.

8. Tjio, I. H., and Levan, A., The use of oxiquinoline in chromosome analysis, Separata de anales de la Estacion Experimental de Aula Dei, 2(1) 21-64, 1959.

9. University of Florida, Annual Report, Agricultural Experiment Stations, p. 127, 1951.

10. University of Florida, Annual Report, Agricultural Experiment Stations, p. 164, 1953.

11. University of Florida, Annual Report, Agricultural Experiment Stations, p. 250, 1954.

12. Young, E. M., and Crocker, C. A., Chromosome studies in Digitaria species, South Afr. J. Sci. 80 258-65, 1933. 